\title{
Front Matter: Volume 11864
}

, "Front Matter: Volume 11864," Proc. SPIE 11864, Remote Sensing Technologies and Applications in Urban Environments VI, 1186401 (19 October 2021); doi: 10.1117/12.2614840

SPIE. Event: SPIE Remote Sensing, 2021, Online Only 


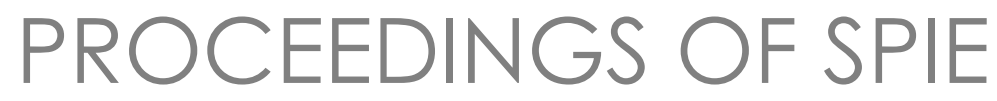

\title{
Remote Sensing Technologies and Applications in Urban Environments VI
}

\author{
Thilo Erbertseder \\ Nektarios Chrysoulakis \\ Ying Zhang \\ Editors
}

13-17 September 2021

Online Only, Spain

Sponsored by

SPIE

Cooperating Organisations

European Optical Society

EARSeL-European Association of Remote Sensing Laboratories (Germany)

ISPRS - International Society for Photogrammetry and Remote Sensing

CENSIS (United Kingdom)

SEDOPTICA

Supporting Organisation

INEUSTAR/INDUCIENCIA

Published by

SPIE

Volume 11864 
The papers in this volume were part of the technical conference cited on the cover and title page. Papers were selected and subject to review by the editors and conference program committee. Some conference presentations may not be available for publication. Additional papers and presentation recordings may be available online in the SPIE Digital Library at SPIEDigitalLibrary.org.

The papers reflect the work and thoughts of the authors and are published herein as submitted. The publisher is not responsible for the validity of the information or for any outcomes resulting from reliance thereon.

Please use the following format to cite material from these proceedings:

Author(s), "Title of Paper," in Remote Sensing Technologies and Applications in Urban Environments VI, edited by Thilo Erbertseder, Nektarios Chrysoulakis, Ying Zhang, Proc. of SPIE 11864, Seven-digit Article CID Number (DD/MM/YYYY); (DOI URL).

ISSN: 0277-786X

ISSN: 1996-756X (electronic)

ISBN: 9781510645721

ISBN: 9781510645738 (electronic)

Published by

SPIE

P.O. Box 10, Bellingham, Washington 98227-0010 USA

Telephone +1 3606763290 (Pacific Time)

SPIE.org

Copyright (C) 2021 Society of Photo-Optical Instrumentation Engineers (SPIE).

Copying of material in this book for internal or personal use, or for the internal or personal use of specific clients, beyond the fair use provisions granted by the U.S. Copyright Law is authorized by SPIE subject to payment of fees. To obtain permission to use and share articles in this volume, visit Copyright Clearance Center at copyright.com. Other copying for republication, resale, advertising or promotion, or any form of systematic or multiple reproduction of any material in this book is prohibited except with permission in writing from the publisher.

Printed in the United States of America by Curran Associates, Inc., under license from SPIE.

Publication of record for individual papers is online in the SPIE Digital Library.

\section{SPIE. DIGITAL}

Paper Numbering: A unique citation identifier (CID) number is assigned to each article in the Proceedings of SPIE at the time of publication. Utilization of CIDs allows articles to be fully citable as soon as they are published online, and connects the same identifier to all online and print versions of the publication. SPIE uses a seven-digit CID article numbering system structured as follows:

- The first five digits correspond to the SPIE volume number.

- The last two digits indicate publication order within the volume using a Base 36 numbering system employing both numerals and letters. These two-number sets start with 00, 01, 02, 03, 04, 05, 06, 07, 08, 09, 0A, OB ... 0Z, followed by 10-1Z, 20-2Z, etc. The CID Number appears on each page of the manuscript. 


\section{Contents}

URBAN AIR QUALITY AND CLIMATE I

$1186404 \quad$ RSLab Landsat land surface temperature application assessment with the new Landsat collection 2 in urban areas [1 1864-1]

1186406 Urban air pollution exposure: an assessment exploiting world settlement footprint and land use data [1 1864-3]

URBAN AIR QUALITY AND CLIMATE II

1186408 A new approach to the estimation of the nighttime land surface temperature [1 1864-5]

1186409 Urban land surface temperature variations with LULC, NDVI and NDBI in semi-arid urban environments: case study of Gaborone City, Botswana (1989-2019) [11864-6]

$11864 \mathrm{OA}$ Comparing the aggregated health risk from air pollution calculated from different Earth observation resources [11864-7]

$11864 \mathrm{OB}$ Profiling the turbulence from spectral measurements in the urban atmosphere using UAVs [1 1864-8]

11864 OC Machine learning approach to estimate windows-to-wall ratio using drone imagery [1 1864-20]

URBAN RESILIENCE AND PLANNING I

$11864 \mathrm{OF} \quad$ Mapping with LIDAR and structure-from-motion photogrammetry: accuracy assessment of point cloud over multiple platforms [11864-11]

URBAN RESILIENCE AND PLANNING II

$118640 \mathrm{~J}$ Crowd change detection from VHR images acquired by UAV via deep features exploitation [11864-15] 
$11864 \mathrm{OL} \quad$ Assessing tree decay in an urban park using PlanetScope images: the case of Cerro Almodóvar Park [11864-17]

$11864 \mathrm{OM}$ Change detection in urban built-up volume using deep learning based segmentation techniques [1 1864-18] 